\title{
The Evaluation of Educational Literacy of Physics Students in Normal Universities Under China's Professional Certification System
}

\author{
Zujun Li1, Qihang Zhou${ }^{1 *}$, Shiwen $\mathrm{Ni}^{2}$, Tian Liang1, Xingyao Han ${ }^{1}$ \\ ${ }^{1}$ Faculty of Science, Jiamusi University, Jiamusi 154000, China \\ ${ }^{2}$ Faculty of Education, University Putra Malaysia, Kuala Lumpur 43300, Malaysia \\ *Corresponding author: Qihang Zhou, 935342242@qq.com
}

Copyright: () 2022 Author(s). This is an open-access article distributed under the terms of the Creative Commons Attribution License (CC BY 4.0), permitting distribution and reproduction in any medium, provided the original work is cited.

\begin{abstract}
This article discusses the connotation of the evaluation of educational literacy of physics students in normal universities, provides the evaluation criteria for students' teaching ability, improves the evaluation composition of educational literacy of physics students in normal universities, and provides the score distribution of the 10 items in educational literacy, in hope to improve the training quality of university students.
\end{abstract}

Keywords: Professional certification; Physics students in normal university; Teaching ability; Educational literacy

Online publication: January 20, 2022

\section{Introduction}

There are significant changes in the quality and professional requirements of today's physics students in normal universities, which inevitably require corresponding optimization of the evaluation system. Exploring the evaluation method and standard system of the education literacy of physics students in normal universities to ensure that graduates meet the requirements of the training program is a topic worthy of research. The scientific evaluation system of the education literacy of physics students in normal universities is the foundation. Only in this way, the cultivation of high-quality applied talents who possess noble educational feelings and innovative spirit, competent in middle school physics education, teaching, and research management, as well as have comprehensive and sustainable development in physics education and teaching can be effectual.

\section{Evaluation of the educational literacy of students majoring in physics}

The evaluation of the educational ability of physics teachers is an activity that makes value judgments on the students' actual or potential middle school physics educational literacy. The purpose is to promote the students' professional development and improve the physics teaching ability, in order to achieve the valueadded process of physics education. It should be a formative evaluation as well as a developmental evaluation, focusing on long-term goals and helping normal students improve their teaching skills. According to the characteristics of students, their personal development goals should be determined, in order to further provide them with training and self-development opportunities, thereby improving their competence in physics education. 
This is a professional evaluation of physics education ability, which is carried out on the basis of physics education professional training plan and practice standards. It recognizes multiple teaching strategies and learning results as well as treats students differently according to different learning tasks, career development stages, and curriculum goals. Evaluation is oriented to diagnostic and analytical practices. The main purpose is to promote the professional development of students in physics education. In terms of value orientation, it pays more attention to the intrinsic quality of life of specific physics students in normal universities as well as the active and healthy development of individual potential. It should be conducive to strengthening the professional ethics education of physics students in normal university, promoting the improvement of the level of physics teaching, and giving full play to the creative, diverse, and new-type evaluation system of physics teachers' educational literacy ${ }^{[1]}$.

There are many contents and a wide range in the process of evaluating the educational ability of physics teachers. Therefore, when constructing a teaching ability evaluation system for students majoring in physics education, full consideration should be given to development, scientificity, feasibility, comprehensiveness, motivation, democracy, bidirectionality, combination of qualitative and quantitative evaluation, information feedback, and simplicity. The evaluation should highlight the future development of students, emphasize the authenticity and accuracy of student evaluation, as well as focus on students' personal, ethical, and professional values. The evaluation should reflect individual thoughts, emotions, preferences, desires, abilities, and the scientific literacy of physics students in normal universities; in addition, it should gradually improve students' self-innovation and development.

\section{Indexes for evaluating the educational literacy of students majoring in physics}

The index system of the ability evaluation system for physics students in normal universities should be designed with the overall goal of achieving the common development of the school, teachers, and students. Generally, it is reflected in four aspects: ability and literacy indicators, learning task indicators, scientific research indicators, and career development indicators. In order to determine the weight of each index, it is necessary to fully solicit the suggestions of teachers and students as well as obtain their support, so that evaluation can play a role in authenticating the educational ability of students.

\subsection{Ability and literacy indicators}

Ability and literacy indicators include moral literacy, knowledge literacy, physical quality, psychological quality, as well as physics education and teaching ability. Moral literacy involves a sense of responsibility and professionalism as well as a spirit of cooperation and innovation. Knowledge literacy consists of basic theoretical knowledge, humanities, scientific and technological knowledge, basic teaching qualities, as well as teaching and research qualities of physics. Psychological quality mainly examines whether the emotion, character, personality, and psychological adjustment of students meet the needs of physics education and teaching. The teaching ability of physics education consists of teaching philosophy, classroom teaching, and student management ${ }^{[2]}$.

\subsection{Learning task indicators}

This refers to the ability to complete the learning tasks with high quality, and the indicators of the completion of various learning tasks in the process of physics education practice, education internship, and education research. It covers the entire learning process as well as the relationship between students and other students, classmates, and intern instructors. 


\subsection{Scientific research indicators}

This refers to the various achievements obtained in the study and scientific research of students, the various awards obtained and research results of scientific research, etc., including published articles, participation in college students' innovation and entrepreneurship projects, participation in teachers' scientific research projects, participation in college student education and teaching competitions, as well as other achievements.

\subsection{Student career development indicators}

The development goal of students is to examine whether they are positive, have a plan for future career development, and have clear goals. This includes the active application for positions, examinations for postgraduates, examinations for civil servants, teaching support, and so on.

\section{Evaluation index of the teaching ability of physics students in normal universities}

Physics teaching ability is the core of the education ability quality system of physics students in normal universities. The training of students' physics teaching ability runs through the whole undergraduate education. All courses should serve to cultivate students' physics teaching ability, not just through the physics education module. The evaluation of physics teaching ability is a complex, systematic, and developmental evaluation, and it is the pillar as well as the soul of the evaluation of physics teachers' education ability.

\subsection{Physics teaching knowledge and ability}

In this evaluation index, it is essential to master physics professional knowledge, skills, experimental design methods, and thinking methods; familiarize with the history of physics development and new development in science and technology; acknowledge the purpose, basic content, and teaching requirements of the General High School Physics Curriculum Standards (Experiments); master the basic theories of physics teaching and be able to use them flexibly in teaching.

\subsection{Ability to design physics teaching}

According to the requirements of the General High School Physics Curriculum Standard (Experiment) and the characteristics of the teaching content, suitable teaching goals can be formulated according to the cognitive laws, basic knowledge, learning needs, and individual characteristics of high school students; the key points and difficulties of classroom teaching should be determined, various teaching resources should be fully utilized, classroom teaching strategies should be optimized, effective teaching methods should be selected, the content of teaching activities should be enriched, interesting physics questions and assignments should be set, students' enthusiasm for learning should be stimulated, and the efficiency as well as the quality of physics teaching should be improved.

\subsection{Ability to implement physics teaching}

According to the characteristics of physics and the cognitive laws of high school students, appropriate teaching methods should be used to guide students to learn efficiently; in addition, it is important to master the strategies of physics theory and experiment teaching, use modern information technology, give play to the teaching functions of multiple media, and use the advantages of network teaching to effectively organize diverse mixed teaching. The teaching content should be summarized and refined in a timely manner, and the teaching plan should be optimized according to students' feedback. 


\subsection{Ability to evaluate physics teaching}

It is important to understand the basic methods and characteristics of physics teaching evaluation, master the basic evaluation methods, and be able to properly evaluate students' learning. The diversification of evaluation goals should be emphasized, and diversified evaluation methods should be used to promote student development. Basic methods and strategies of physics teaching reflection should be used to sort out and reflect on the teaching process and then propose ways to improve teaching. The selected teaching methods and procedures should be continuously revised through physics evaluation to ensure the achievement of teaching goals, and at the same time provide information reference and data support for physics teaching research ${ }^{[3]}$.

\subsection{Educational qualification for students majoring in physics education}

In order to train qualified middle school physics teachers and reflect their professional characteristics, it is necessary to conduct a comprehensive evaluation of the students majoring in physics education. The evaluation system should cover political literacy and moral literacy, enthusiasm for education, physics literacy, teaching ability, class guidance ability, comprehensive education ability, learning and reflection ability, communication and cooperation ability, etc. The evaluation of each aspect and the weight distribution are subjects worth exploring. According to the current research situation, a comprehensive quality evaluation is shared as shown in Table 1, and the weight distribution of each literacy is shown in Figure 1. Only students with 60 points or more can graduate and take on the post of physics education and teaching.

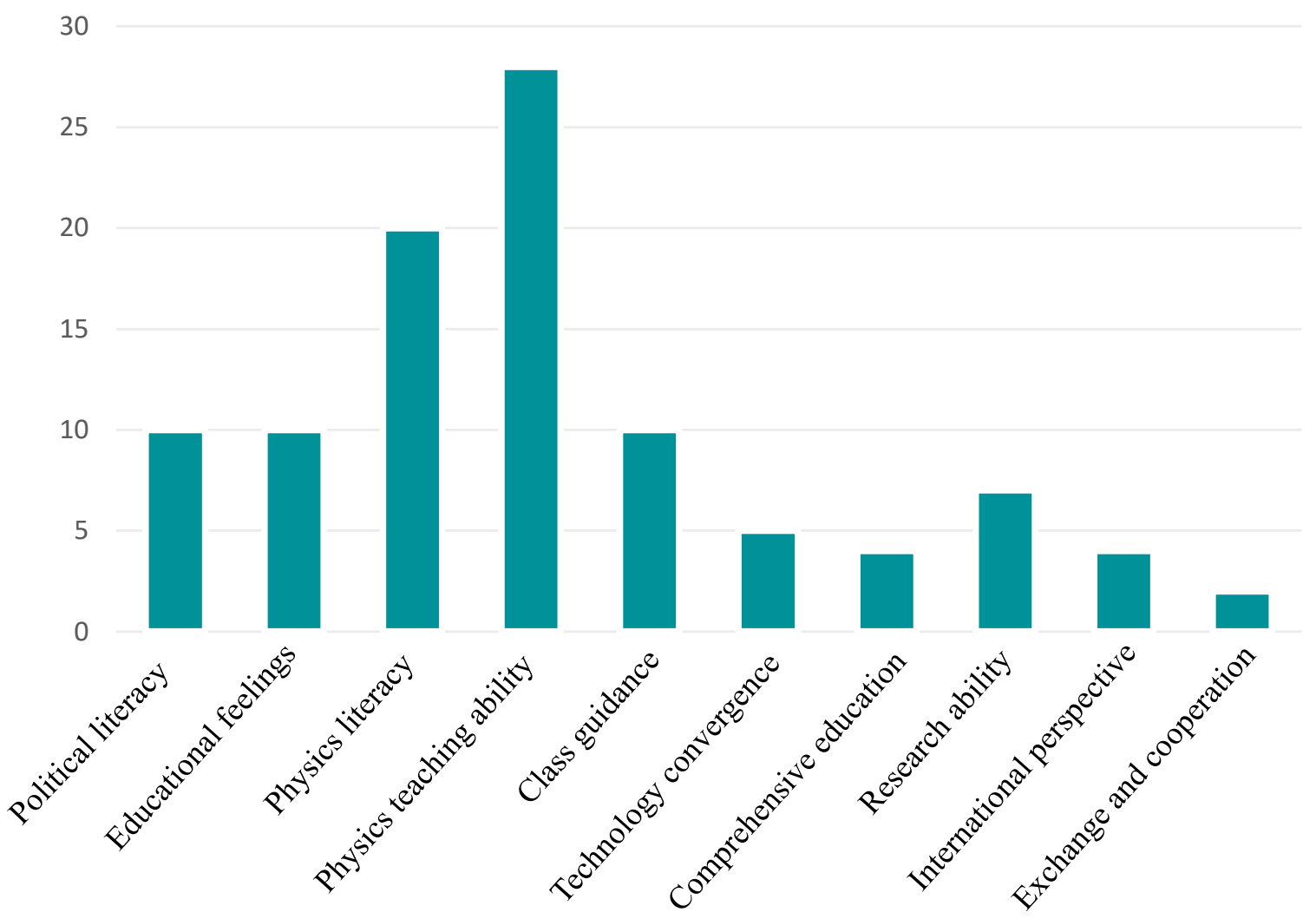

Figure 1. Score distribution of each item in educational literacy 
Table 1. Educational literacy checklist

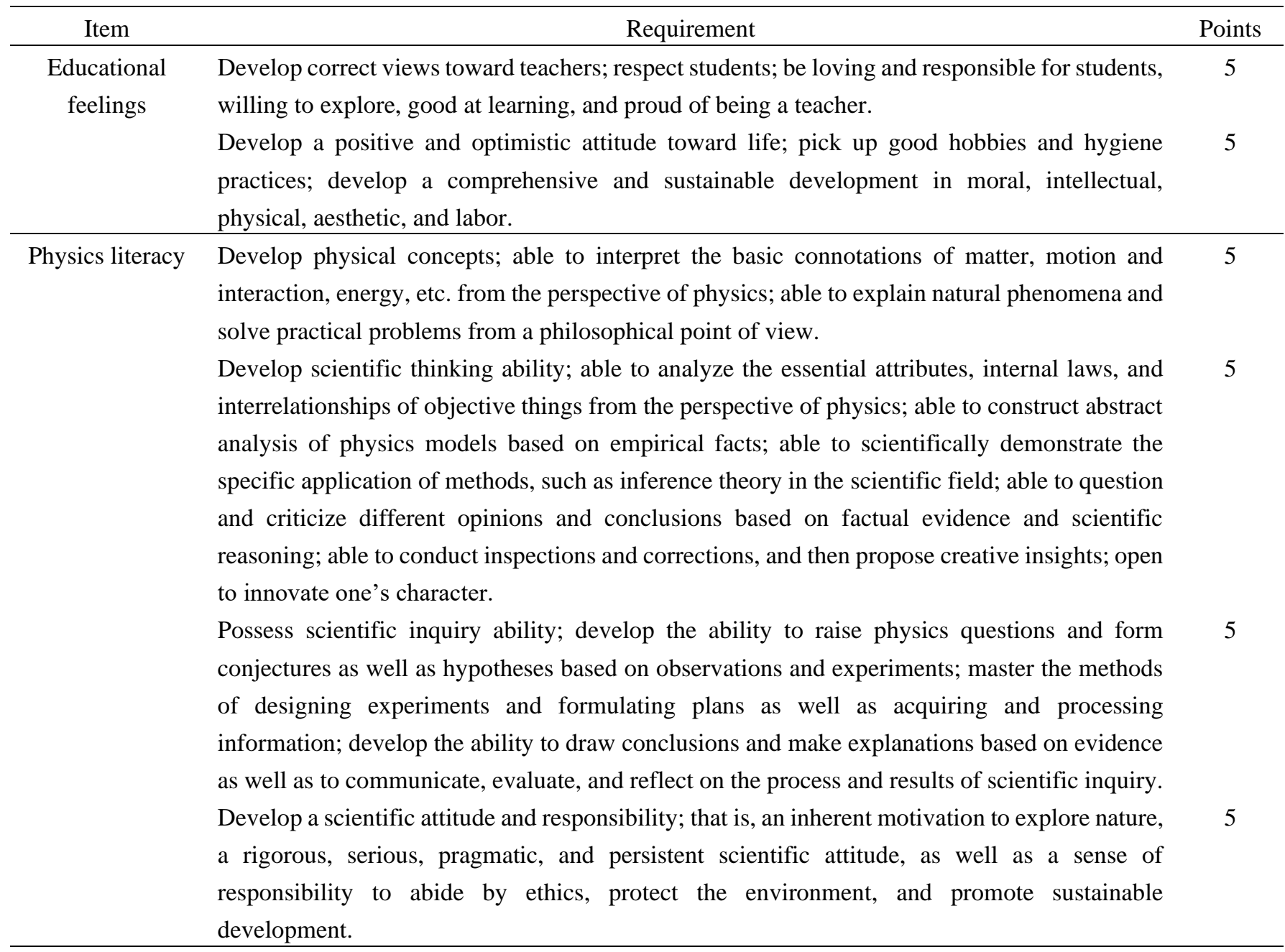

Physics teaching Master basic educational theories, such as pedagogy, psychology, and introduction to physics ability education; effectively guide middle school physics teaching and practice activities based on the physical and mental development of middle school students as well as the cognitive characteristics of the subject along with the actual situation of the students and learning contents.

Being familiar with middle school physics curriculum standards; understand the concepts of middle school physics curriculum standards; master the ideas and basic conditions of the compilation of middle school physics textbooks and teaching parameters; able to reasonably analyze and integrate knowledge points; able to develop or redevelop physics courses.

Master the basic physics thinking methods; understand the history of physics development and 5 physics culture; understand the connotation of middle school physics knowledge.

Possess solid basic teaching skills; being proficient in the use of software to assist teaching; able to use modern information technology to innovate teaching methods; able to choose appropriate teaching methods, and design teaching programs; learn the basic methods of observation and analysis in physics classroom; able to reflect in time after class and make rational assessment.

(Continued on the next page) 


\begin{tabular}{|c|c|c|}
\hline Project & Requirement & Points \\
\hline \multirow[t]{2}{*}{ Class guidance } & $\begin{array}{l}\text { Master effective methods and strategies for collective education and individual education; } \\
\text { develop the skills to communicate with students, colleagues, and parents; able to establish a } \\
\text { learning community and properly respond to emergencies. }\end{array}$ & 6 \\
\hline & $\begin{array}{l}\text { Able to effectively organize educational activities, such as moral education and mental health } \\
\text { education, in accordance to the actual situation of the class and the characteristics of the } \\
\text { students. }\end{array}$ & 4 \\
\hline \multirow[t]{2}{*}{$\begin{array}{l}\text { Technology } \\
\text { convergence }\end{array}$} & $\begin{array}{l}\text { Possess the profound humanistic background and scientific spirit, the consciousness and ability } \\
\text { to use physics knowledge to solve practical problems, the ability of interdisciplinary and } \\
\text { interprofessional application, as well as other comprehensive literacy of subjects suitable for } \\
\text { middle school physics education. }\end{array}$ & 5 \\
\hline & $\begin{array}{l}\text { Master the basic theories of mathematics, computer, and other interdisciplinary subjects; } \\
\text { develop the awareness and ability to use physics knowledge, experiments, and computer } \\
\text { software to solve physics and interdisciplinary problems. }\end{array}$ & 5 \\
\hline $\begin{array}{l}\text { Comprehensive } \\
\text { education }\end{array}$ & $\begin{array}{l}\text { Understand the value of physics education; able to effectively use physics teaching to integrate } \\
\text { education topics and other contents; able to grasp the laws of physical and mental development } \\
\text { of middle school students, the characteristics of learning and growth, as well as the educational } \\
\text { needs while taking into account of the actual situation of the class; effectively organize thematic } \\
\text { education, club activities, and other educational activities. }\end{array}$ & 4 \\
\hline \multirow[t]{3}{*}{ Research ability } & $\begin{array}{l}\text { Familiar with the use of a foreign language and computer technology; master the basic methods } \\
\text { of data query, document retrieval, and the use of modern technology to obtain relevant } \\
\text { information; able to actively analyze relevant information; develop strong reading, retrieval, } \\
\text { and writing skills. }\end{array}$ & 2 \\
\hline & $\begin{array}{l}\text { Have a certain sense of innovation; able to determine and put forward problems in physics } \\
\text { teaching; able to use educational scientific research methods to analyze and solve physics } \\
\text { teaching problems; develop strong practical application capabilities. }\end{array}$ & 2 \\
\hline & $\begin{array}{l}\text { Master reflective methods and skills; learn to use critical thinking methods to analyze and solve } \\
\text { problems in physics education and teaching. }\end{array}$ & 3 \\
\hline \multirow[t]{2}{*}{$\begin{array}{l}\text { International } \\
\text { perspective }\end{array}$} & $\begin{array}{l}\text { Have a solid foundation in English language and communication skills; develop the ability to } \\
\text { communicate internationally; become a learner who accepts new ideas and is able to apply them } \\
\text { to practical work. }\end{array}$ & 2 \\
\hline & $\begin{array}{l}\text { Have a certain level of understanding in physics theory; understand the development of basic } \\
\text { education reforms at home and abroad; recognize the application value, scientific value, and } \\
\text { cultural value of physics; form critical thinking habits; advocate the rational spirit of physics; } \\
\text { experience the aesthetic significance of physics. }\end{array}$ & 2 \\
\hline \multirow[t]{2}{*}{$\begin{array}{l}\text { Exchange and } \\
\text { cooperation }\end{array}$} & $\begin{array}{l}\text { Be able to recognize the important role of the learning community; understand the important } \\
\text { meaning of teamwork in education and throughout the teaching process; develop the spirit of } \\
\text { teamwork. }\end{array}$ & 1 \\
\hline & $\begin{array}{l}\text { Master communication and cooperation skills; actively carry out group mutual assistance and } \\
\text { cooperative learning; exchange practical experiences; discuss and solve problems together. }\end{array}$ & 1 \\
\hline
\end{tabular}

\section{Conclusion}

The purpose of professional certification is to improve the training quality of students. Universities must take this opportunity to set up scientific teaching curriculums and teaching systems, increase experimental 
practice links, strengthen educational practice contents, as well as establish a scientific and reasonable quality evaluation system for students. It is essential to cultivate graduates with political consciousness and socially oriented educational feelings as well as those who can master modern educational technology, possess core literacy in physics, and have higher education, teaching capabilities, as well as innovative qualities while delivering high-quality physics teachers to the society.

\section{Funding}

The Research Project of "Research on Innovation and Entrepreneurship Practice Mode of Science and Engineering College Students" (Project Number: XJYT201703).

\section{Disclosure statement}

The authors declare that there is no conflict of interest.

\section{References}

[1] Li Z, Ma J, Yu X, et al., 2017, Physics Education Measurement and Evaluation. Jilin Education Publishing Group Co., Ltd., 2017: 234-235.

[2] Chen Q, Li Z, Cai X, 2018, Analysis of the Status Quo of Ordinary High School Students Learning Physics Under the Background of the New College Entrance Examination. Middle School Physics, 36(19): 61-62.

[3] Liu H, Fei J, 2020, Analysis of the Connotation, Characteristics and Status Quo of the Teaching Literacy of Physics Normal Students. Examinations and Evaluation, 2020(11): 149. 